\title{
CASP2 wt Allele
}

National Cancer Institute

\section{Source}

National Cancer Institute. CASP2 wt Allele. NCI Thesaurus. Code C49552.

Human CASP2 wild-type allele is located within $7 q 34-q 35$ and is approximately $19 \mathrm{~kb}$ in length. This allele, which encodes caspase-2 protein, plays a role in the activation of caspase-dependent apoptosis. 